\title{
Memória e história: 0 uso da mídia fotografia para a recuperação histórica da construção da usina hidrelétrica de Capivara, na visão de antigos trabalhadores de Iepê
}

\author{
Autora: Adgélzira Capeloti Pereira \\ Orientador: Paulo César Boni
}

Resumo: Recuperar informações referentes ao período de construção da Usina Hidrelétrica de Capivara, a partir da visão de ex-trabalhadores de Iepê, município mais impactado pela obra. Esse é um dos objetivos deste trabalho, que busca também testar e sistematizar a proposta metodológica que utiliza a mídia fotografia como disparadora do gatilho da memória, desenvolvida pelo grupo Comunicação e História da Universidade Estadual de Londrina. A metodologia que, até então, havia sido aplicada para recuperação histórica de fatos referentes à fundação de municípios de trajetória recente, com entrevistas de pioneiros, dessa vez tem seu foco voltado à década de 1970. Nesse período, Iepê teria experimentado significativo desenvolvimento econômico por conta das obras de infraestrutura executadas para acomodação de trabalhadores advindos de diferentes regiões do país. Para o processo de pesquisa empírica foi composto um portfólio com 10 imagens de diferentes fases da construção da barragem e selecionados 10 ex-trabalhadores residentes no município para contar sobre as lembranças suscitadas pelas fotografias. $O$ resultado alcançado demonstra que a metodologia se apresenta como importante ferramenta para recuperação de dados históricos, a partir de memórias quase apagadas pela ação do tempo. Dessa forma, foi possível confirmar o poder de informação, aproximação e emoção emanados pelas imagens, que tornoram possível a reconstituição de quadros dos cenários econômico, social, trabalhista, cultural, políticoadministrativo da usina de Capivara e também de Iepê.

Palavras-chave: Fotografia e memória. Gatilho da memória. Usina Hidrelétrica de Capivara. História de Iepê (SP). Relações de trabalho. 


\title{
Memory and History: the use of the media picture to historical recovery of the construction of Hydroelectric Power Plant Capivara, in the view of former workers of Iepê
}

\begin{abstract}
Retrieve information for the period of construction of the hydroelectric plant Capivara, from the vision of former workers of Iepê, municipality most affected by the work. This is one of the objectives of this work, which also seeks to test and systematize the methodological approach that uses photography media as triggering the memory trigger, developed by the group Communication and History of UniversidadeEstadual de Londrina. The methodology that, until then, had been applied to recovery history of facts concerning the foundation of recent trajectory of municipalities, with interviews of pioneers, this time focuses back to the 1970. During this period, Iepê would have experienced significant economic development by account of infrastructure works performed for accommodation of workers coming from different regions of the country. For the empirical research process comprised a portfolio of 10 images at different stages of dam construction and selected 10 former workers residing in the city to tell about the memories raised by the photographs. The result achieved demonstrates that the methodology is presented as an important tool for retrieval of historical data from memory almost erased by time. Thus, it was possible to confirm the power of information, approach and emotion emanating from the images, which tornoram possible reconstitution of frames of economic scenarios, social, labor, cultural, political and administrative of Capivara the plant and alsolepê.
\end{abstract}

Keywords: Photography and Memory. Trigger of memory. Hydroelectric Power Plant Capivara. History Iepê (SP). Labor relations. 